\title{
Peningkatan Motorik Kasar Melalui Pembelajaran Daring Berbasis Whats App
}

\author{
Diah Puspita Andini' ${ }^{1}$, Marlinah $^{2}$, Nurchahyani ${ }^{3}$, Sesiyana Apriyanti ${ }^{4}$, Esnirani \\ Silaban ${ }^{5}$, Irma Yuliantina ${ }^{6}$ \\ diahandini49@gmail.com¹, marlinahsukses@gmail.com², nurchahyani11@gmail.com³, \\ Sesiapriyanti02@gmail.com ${ }^{4}$, esnirani1@gmail.com ${ }^{5}$, irma_antina@yahoo.co.id \\ Program Studi: Pendidikan Guru Pendidikan Anak Usia Dini 1,2,3,4,5, Universitas Panca Sakti \\ Bekasi 1 ,2,3,4,5,6
}

\begin{abstract}
Improving learning through rough motoric activities using WhatsApp application at RA Al Muttaqin. This research was implemented using offline (Visit School) and online (WhatsApp applications) methods as a problem solver for teaching and learning activities (KBM) at RA Al Muttaqin during the Covid-19 pandemic. Based on the results of motoric physical activity through WhatsApp learning was applied by making video of learning to know children's rough motoric development. Generally, WhatsApp-based online learning challenges teacher's creativity, in planning fun and interesting learning programs by developing collaboration between teachers, parents and participants, that is become the best solution in the Covid-19 pandemic that demands to take care of the physical.
\end{abstract}

Keywords: covid-19 pandemic, whats app, online learning

\begin{abstract}
Abstrak
Peningkatan pembelajaran pada RA Al Muttaqin melalui kegiatan motorik kasar dengan Aplikasi Whats App. Kegiatan penelitian ini dilakukan dengan menggunakan metode luring (Visit School) dan daring (Aplikasi Whats App) sebagai pemecah masalah kegiatan belajar mengajar (KBM) di RA Al Muttaqin di masa pandemi covid-19. Berdasarkan hasil kegiatan fisik motorik melalui pembelajaran berbasis whatsapp tatap terlaksana sesuai harapan, dengan membuat vidio pembelajaran untuk mengetahui perkembangan motorik kasar pada anak. Secara umum, pembelajaran daring berbasis whatsapp menantang kreatifitas guru, dalam merencanakan program pembelajaran yang menarik dan menyenangkan dengan membangun kerjasama antara guru, orang tua dan peserta yaitu menjadi solusi terbaik di pandemi covid-19 yang menuntut untuk jaga fisik.
\end{abstract}

Kata Kunci: pandemi covid-19, whats app, pembelajaran daring

\section{PENDAHULUAN}

Sekolah RA Al Muttaqin merupakan Sekolah Raudhatul Athfal yang berlokasi di Jl. Pangrango Terusan No. 19-A Rt 004 Rw 007, kelurahan: Jatibening Baru. Kecamatan:Pondogede. Kota Bekasi. 17412. Dengan jumlahkeseluruhan kelas yang dikelola RA Al Muttaqin sebanyak 5 ruang kelas yang terdiri dari 76 peserta didik dan memiliki 10 orang guru. Proses kegiatan KBM yang berlansung di RA Al Muttaqin yang didampingi oleh 2 orang guru dimasing-masing kelas, di fasilitas ruang kantorkepala 
sekolah dan para guru, ruang kelas, aula bermain, dan masjid. Gambaran sekolah ini cukup memiliki fasilitas yang memadai dalam penyelenggaraan pendidikan anak berbasi nilai-nilai keislaman.

Dalam situasi saat ini dapat memperlihatkan bahwasanya sekolah RA Al Muttaqin terbilang sudah di dukung oleh kemampuan yang sudah cukup baik, dan memadai di dalam setiap bidangnya. Walaupun demikian keunggulan dari sekolah RA Al Muttaqin masih dapat terbilang belum begitu baik. Alhamdulilah selama 1 tahun belakangan ini proses kegiatan pembelajaran yang berlangsung di RA Al Muttaqin sedikit mengalami masalah yang disebabkankarena terjadinya Pandemi Covid-19. Berdasarkan dengan adanya surat edaran darikemendikbud yaitu: No. 4 Tahun: 2020, menjelaskantentang adanyapelaksanaan kebijakan dari pendidikan dalam situasi dimasa darurat adanya penyebaran corona virus disease atau yang biasa disebut (covid-19). Dalam keadaan ini proses terjadinya belajar mengajar yang akan dilakukan dari rumah dengan metode pembelajaran online (daring).
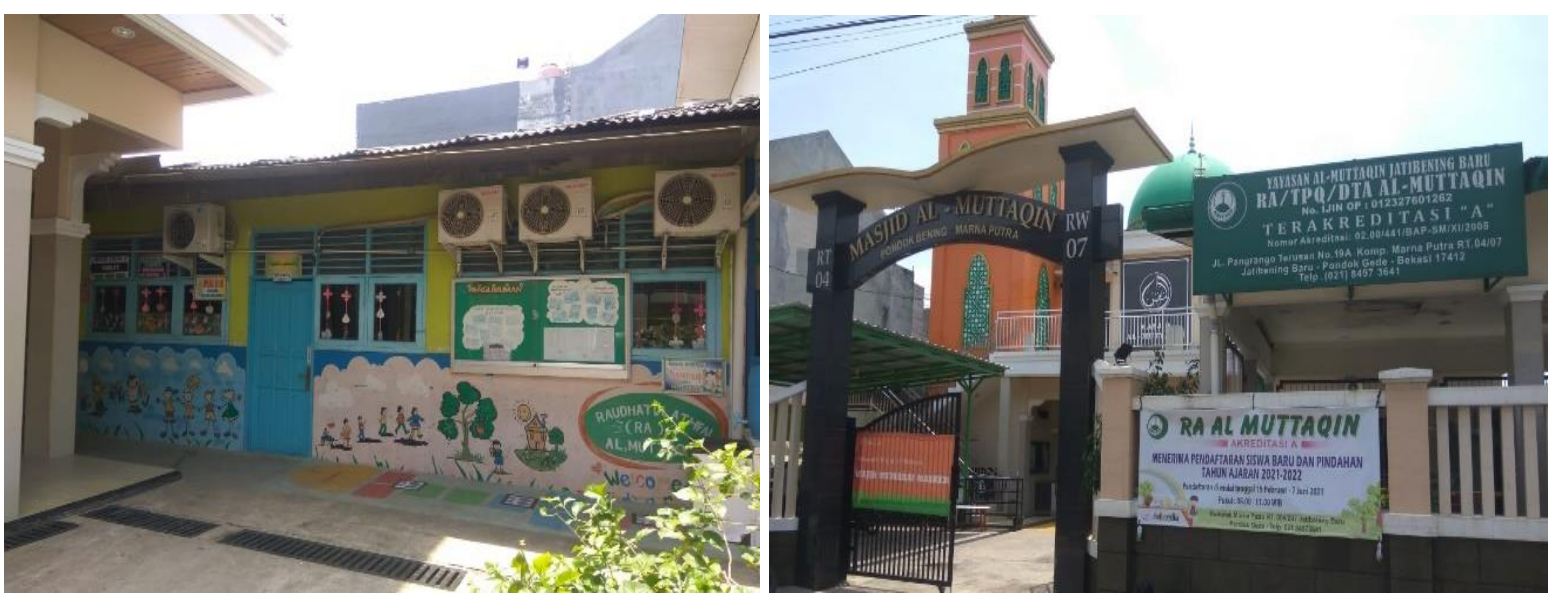

Gambar 1: Lokasi Gambaran Loaksi RA Al Muttaqin

Kegiatanserta tugas yang akan diberikan oleh pihak sekolah RA Al Muttaqin dalam proses pembelajaran online (daring) yang akan dilakukan bermacam-macam pilihankepada orang tuapeserta didik, sesuai kondisi masing-masing dilingkungan sekitar dan mempertimbangkan dari kesenjangan fasilitas/akses dari rumah dengan Metode Pembelajaran yang akan digunakan di RA Al Muttaqin yaitu anatra lain: 1) Home Visit, 2) Visit School (Luring), 3) Pembelajaran Daring melalui aplikasi whatsapp seperti antara lain:vidio call, vidio, rekaman suara dan foto.

Dalam melakukan pembelajaran di masa pandemi RA Al Muttaqin memiliki berbagai macam metode pembelajaran, diantaranya: 1) Home Visit, ialah kunjungan seorang tenaga pendidik secara langsung ke rumah peserta didiknya yang dilakukan untuk alternatif belajar anak pada pandemi covid19; 2) Pembelajaran daring, ialahmetode belajar yang digunakan sebagai model interaktif yang menggunakanbantuan internet dan Learning Manajemen System (LMS), seperti menggunakan aplikasi whatsapp di RA Al Muttaqin serta sebagainya; 3)Visit School (Luring), ialah kunjungan peserta didikdatang ke sekolah untuk belajar disekolah dengan waktu yang lebih singkat serta untuk peserta didik dapat mengumpulkantugas/hasil belajar anak selama pembelajaran daring ataupun kegiatan belajar di rumah masing-masing.Berdasarkan pada hasil penelitian bahwa dalam keadaan pembelajaran dimasa pandemi covid-19 menghasilkan peroleh data analisis yaitu (1) pembelajaran masihharus ditingkatkan untuk meminimalisir masalah yang tidak bisa dikendalikan dikemudian hari 
nanti. (2) dalam memanfaatkan Iptek untuk menyelenggaraan kegiatan pembelajaran yang di rancang oleh seorang guru, agar dapat mengembangkan pembelajaran dengan menggunakan aplikasi whatsapp.

Teknologi dalam penggunaanya dapat membantu proses pembelajaran yang memberikan persembahan untuklebih baik dalam meningkatan kualitas pembelajaran, adapun beberapa pihak lain dalammemanfaatkan teknologi dapat berakibat dalam hal yang kurang baik bila salah satu dalam pemanfaatanya. Dalam hal tersebutdijelaskan dari Pusat Teknologi, Komunikasi dan informasi dalam Pendidikan Kemendikbud Republik Indonesia.Dalam kegiatan Iptek dapat berjalan baik dengan pembelajaran yang dilengkapi dengan pembelajaran yang sesuai untuk kebutuhan pembelajaran peserta didik. Pembelajaran disusun ataupun direncanakan sesuai dengan tujuan program pengembangan pembelajaran (Purwanto, 2004).

Menurut(Pannen dalam Sadjati, 2012)mengatakan bahwa pembelajaran ialah materi serta bahan ajar yang dibuatsecara sistematis, untuk dipergunakan seorang guru serta peserta didikuntuk kegiatan proses pembelajaran.Pembelajaran yang dikategorikan ataupun syaratpembelajaran yang dibutuhkan melalui kegiatan pendampingan semua kesulitandapat ditupas dengan tuntas.Seorang guru membimbing serta mendidik dan membuat rencana penyusunan pembelajaran serta pelaksanaan pembelajaan dengan memanfaatkan aplikasi whatsapp untuk tetap berjalannya proses pembelajaran di RA Al Muttaqin. Oleh karena itu, banyak hal yang menghubungkan yang di hadapi RA Al Muttaqin dalam melaksanakan pembelajaran salah satunya adalah kegiatan motorik kasar pada anak didik kemampuan fisik motorik suatu faktor dimana sangat penting untuk perkembangan anak secara total, karena pertumbuhan serta perkembangan fisik yang terjadi mulai dari bayi hingga dewasa.

Kemampuan fisik motorik pada anak dapat mempengaruhi setiap kehidupan anak sehari-hari, dengan kemampuan fisik motorik anak tumbuh dengan baik, pertumbuhan yang lainnya akan berkembang dengan sangat baik. Anak yang mempunyai kemampuan pada motorik kasar nya baik, anak akan mempunyai kemampuan serta perkembangan pada mentalnya baik, karena anak yang bisa menyesuaikan dirinya dari lingkungan disekitarnya sehingga rasa percaya diri dalam dirinya akan terus meningkat serta berpengaruh positif dalam kemampuan kognitifnya. Adapun Unsur utama yang berperan sangat penting dalam stimulasi perkembangan motorik pada anak.

Fikriyati, (2013) mengatakan bahwa keterampilan motorik erat berkaitan dengan perkembangan pengendalian gerakan badan dengan aktivitas yang terkoordinir antara lapisan saraf, otot, otak, serta spinal cord.Motorik Kasar ialah sebagian gerakan badan yang mengawasi otot besar ataupun sebagian besar maupun semua anggota badan, dengan kematangan anak tersebut. Sedangkan bagi Catron serta Allen (dalam Sujiono, 2009: 63) mengemukakan kalau keahlian motorik pada dasarnya ialah peluang yang luas buat bergerak, pengalaman belajar buat menciptakan, kegiatan senssori motor yang meliputi pemakaian otot- otot besar serta kecil membolehkan anak buat penuhi pertumbuhan perseptual motorik.

Hurlock (dalam Saputra \& Rudyanto 2005: 17) menarangkan kalau pertumbuhan motorik berarti pengendalian gerakan jasmaniah lewat aktivitas pusat syaraf, urat syaraf, serta otot yang dikoordinasikan. Motorik ialah pengendalian gerakan badan lewat kegiatan yang terkoordinir antara lapisan saraf, otot, otak serta urat saraf tulang balik (spinal cord), sebaliknya kegiatan motorik agresif ketrampilan gerak ataupun gerakan badan yang mengenakan otot- otot besar selaku dasar utama 
gerakannya. Ketrampilan motorik agresif meliputi pola lokomotor (gerakan yang menimbulkan perpindahan tempat) semacam berjalan, berlari, menendang, naik- turun tangga, melompat, meloncat, serta sebagainya. Pula ketrampilan memahami bola semacam melontarkan, menendang, serta memantulkan bola.

Bersumber darisebagian penafsiran oleh para pakar, hingga bisa mengatakan bahwa keterampilan motorik kasar merupakan hubungan yang berhubungan dengan gerakan otot-otot besar dalam melaksanakan gerakan badan lewat keahlian lokomotor, non lokomotor, serta manipulatif. Latihan aktivitas yang berhubungan dengan motorik agresif serta motorik halus butuh dikoba secara teratur tingkatkan keahlian anak dalam pelatihan serta melaksanakan gerakan badan secara baik dan efisien, yang muat Kegiatan koordinasi dengan tangan maupun mata, koordinasi indra, dan anggota tubuh, keberanian, keberanian, kepercayaan diri, serta melatih kesiapan diri sebelum beraktivitas (Kusumaningtyas, 2016).

Melalui konsep keterampilan motorik kasar sangat berkaitan dengan ketrampilan anak dalam menggerakkan otot besar nya, lengan serta kaki.Kurtz (2014, menjelaskan keterampilan motorik kasar pada gerakan tubuh yang melibatkan kelompok otot besar dan gerakan tubuh total.Contohnya seperti merangkak, berlari, menyeimbangkan, melempar, serta menangkap bola atau memanjat dengan peralatan bermain.Hal ini terjadi bahwa kemampuan motorik kasar adalah garakan badan yang melibatkan otot-otot besar dan pergerakan tubuh secara keseluruhan, contoh adalah merangkak, berjalan, berlari, keseimbangan, melempar, menangkap bola, atau memanjat (Hayati, 2020,).

Permasalahan yang dihadapi masa pandemi covid- 19 dimana menuntut seorang guru selaku tenaga pendidik, senantiasa untuk dituntut tetap menjalakan pembelajaran di sekolah. Pada pembelajaran tatap muka (Luring), seorang guru lebih bebas menerapkan modul pelajaran yang telah dirancang serta memperhitungkan motivasi belajar para paserta didiknya. Di masa pandemi dengan melalui pembelajaran serba online atau pembelajaran (Daring), seorang guru diharapkan bisa lebih kreatif dan inovatif dalam membuat bahan ajar yang lebih menarik serta semangat peserta didik, tidak hanya itu seorgang guru pula yang dituntut untuk teliti dalam kemampuan pengetahuan dan teknologi (Syaharuddin, S., \& Mutiani, Meter., 2020). Pembelajaran akan tetap tinggal pendidikan tetap terjamin. Tugas utama dan fungsi seorang guru yang melekat akan tetap dilaksanakan, karena seorang guru diharapkan dapat menjalankan pendidikan serta pembelajaran, maka seorang guru dituntut agar lebih kreatif sebagai fasilitator dalam penyusun pembelajaran. Pembelajaran daring biasanya adalah pembelajaran yang selama ini dapat dilakukan oleh seorang guru secara interaktif melalui video pembelajaran (Muhammad, 2020). Pembelajaran masalah daring adalah sesuatu cara menanggulangi pendidikan serta penyelenggaraannya. Pembelajaran daring merupakan metode pembelajaran yang menggunakan model interaktif berbasis aplikasi Whats App.

Pemilihan aspek motorik kasar yang dikembangkan adalah selama pembelajaran dilakukan di rumah anak seharusnya bergerak tetapi karena keterbatasan orang tua mendampingi anak belajar akhirnya dominasi anak kurang dalam bergerak sehingga anak perlu distimulasi dalam gerakan.Pemilihan aplikasi whashap karena keterbatasan orang tua maka hanya menggunakan aplikasi ini yang mudah dipahami sehingga dapat menyampaikan panduan pembelajaran aspek motoric kasar pada anak selama di rumah. 


\section{METODE PENELITIAN}

Penelitian ini ialah menggunakan Metode Penelitian Tindakan, dengan menggunakan model Kemmis dan Taggart, setiap siklusnya mengikuti langkahsistematis sesuai kaidah-kaidah dari penelitian serta kebutuhan parameter penelitian. Tahapanpenelitian ini dengan model Kemmis dan Taggart meliputi: Planiing (perencanaan),Action (tindakan), Observation (pengamatan), dan Reflection (refleksi) melalui 2 siklus karena tidak dilanjutkan siklus 3 sudah terjadi peningkatan.

Penelitian dilaksanakan di RA Al Muttaqin Kecamatan: Pondokgede, Kota Bekasi. Penelitian dilaksanakan pada saat semester 2,tahun pelajaran 2020/2021, pada bulan Februari 2021. Data dalam penelitian ini ialah anak peserta didik kelompok B, di RA Al Muttaqin yang terletak di kecamatan: Pondokgede, Kota Bekasi. Provinsi: Jawa Barat. Selanjutnya terdapat 17 anak yang dijadikan sumber data yang terdiri dari 8 anak perempuan dan 4 anak laki-laki.

Desain metode penelitian ini, ialah tindakan serta pengamatan yang dijadikan sebagai satukesatuan dikarenakan kedua komponen itu merupakan dua kegiatan yang tidak dapat dipisahkan. Syarat keberhasilan dari tindakan dalam penelitian ini yang mengikuti standar Mills ialah sebanyak $71 \%$ dari jumlah peserta didik. Teknik dari pengumpulan data yang digunakan dalam penelitian ini ialah wawancara, catatan observasi dan dokumentasi. Wawancara dalam penelitian ini dilakukan kepada guru dari kelompok: B di RA Al Muttaqin Jatibening Baru, Kecamatan: Pondokgede. Catatan observasi terdiri dari apa yang dilihat, didengar, serta yang dipikirkan oleh peneliti ini dalam rangka mengumpulkan data. Dokumentasi dalam penelitian ini yaitu mengumpulkan informasi tentang kemampuan motorik kasar anak berupa foto dan video.

Kisi-kisi instrumen yang dikembangkan dengan melalui defenisi konseptual serta operasional yang menjelaskan bahwa keterampilam motorik kasar ialah gerakan yang dilakukan anak untuk melibatkan sebagian ataupun keseluruhan anggota badannya seperti gerak lokomotor, gerak non lokomotor serta gerakan manipulatif dalam ditiap komponen koordinasi, keseimbangan, kecepatan, kelincahan, serta kekuatan.

\section{HASIL DAN PEMBAHASAN}

\section{Peningkatan Motorik Kasar Melalui Pembelajaran Daring Berbasis Aplikasi Whatsapp}

Implementasi upaya meningkatkan kemampuan motorik kasar melalui pembelajaran daring berbasis aplikasi whats app ialah tahapan pemaparan materi pembelajaran, melalui aplikasi whatsappchat group RA Al Muttaqin yang digunakan untuk integrasi antara pihak sekolahseperti kepala sekolah dan guru kepada wali murid peserta didik RA AI Muttaqin yang berlangsung dalam waktu nyata. (1) Fasilitas Share Dokumen pembelajaran digunakan untuk membantu kelompok belajar mengirim dokumen dalam bentuk file vidio pembelajaran; (2) Foto kegiatan yang digunakan untuk hasil dari laporan kegiatan anak, foto kegiatan yang dilakukan anak saat belajar di rumah untuk melaporkan hasil dari kegiatan yang dilakukan pada proses belajar anak.

Hasil pembelajaran di rumah yang dilakukan anak dengan melalui aplikasi whatappanak dapat mempergunakannya untukmelaporkan atau mengirimkan sebuah hasil kegiatan yang dilakukan anak berupa gambar, vidio ataupun rekaman suara.Berdasarkan dari para orang tua peserta didik yang sangat berperan sebagai pembimbing sekaligus sebagai motivator bagi anak-anaknya saat anak belajar di rumah bersama orang tuanya.Masalah yang dirasakan oleh para orang tua peserta didik yaitu seperti yang dirasakan oleh Mahrita (47 tahun), mengatakan bahwa tanggung jawab sebagai seorang pengajar 
menggantinya dengan melakukan kegiatan pembelajaran di rumah di masa pandemi covid-19 ini yang tidak dapat dianggap remeh, dikarenakan harus membagi waktu mengerjanya pekerjaan rumah serta membimbing peserta didik pada saat pembelajaran online (Daring).Mengapa orang tua peserta didik kadang sulit dalam mengganti peran seorang guru dalam mengajarkan anaknya dirumah ialah karena profesi seorang guru guru itu ialah memerlukan keahlian khusus serta kesabaran dalam mendidik anak dan tidak semua orang dapat melakukannya oleh sembarang orang yang basic-nya yaitu tidak dari bidang pendidikan keguruan (Subiyakto, B., \& Akmal, H., 2020).

\section{Hasil Serta Luaran Yang Tercapai}

Kegiatan serta hasil dari pelaksanaan program pembelajaran online berbasis aplikasi whatsapp grup di sekolah RA Al Muttaqin, kelurahan: Jatibening Baru, kecamatan: Pondokgede.Tujuan untuk mendapatkan luaran sesuai yang diharapkan ialah kegiatan serta hasil yang dapat diungkapkan seperti berikut:

\section{Program Pendampingan Belajar PesetaDidik Berbasis Aplilasi WhatsApp}

Kegiatan yang awali dalam melaksanakan sosialisasi suatu kegiatan belajar mengajar, yang merupakan pendampingan system pembelajaran online berbasis aplikasi whatsapp grup yang dilakukan untuk memberikan informasi secara menyeluruh dari pihak sekolah kepada orang tua peserta didik serta pemberian materi pembelajaran dalam proses kegiatan belajar mengajar peserta didik di RA Al Muttaqindengan pemberian materi pembelajaran seperti kegiatan pembiasaan seperti: melafalkan asmaul husna, surat pendek dalam Al Qur'an, mutiara hadist serta doa harian serta pembiasaan lainnya.

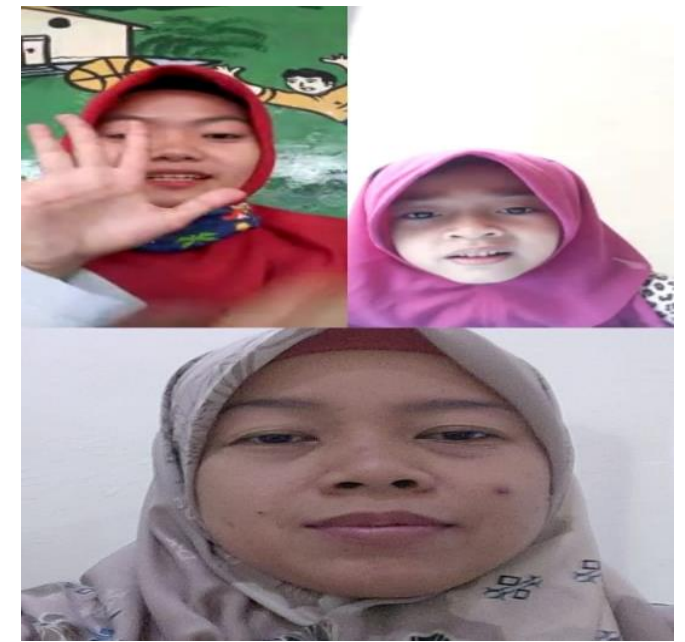

Gambar 3. Kegiatan pendampingan belajar daring, berbasis aplikasi media whatshApp

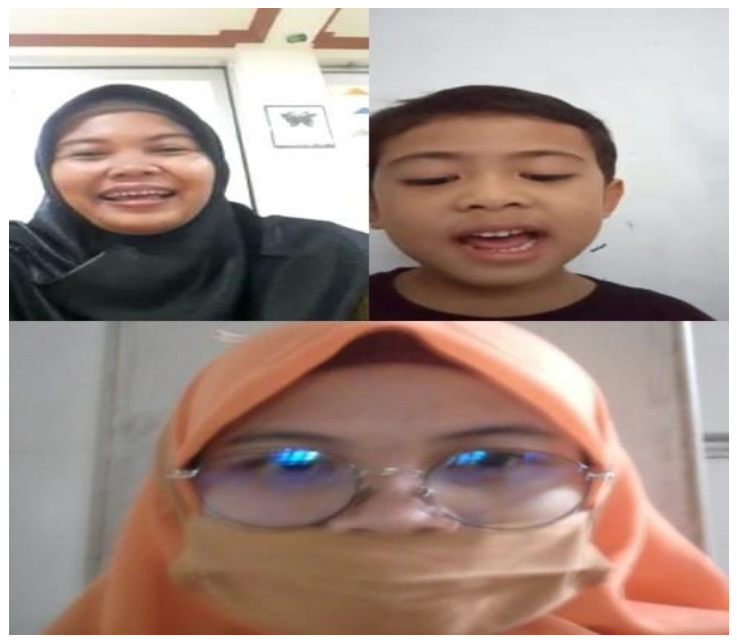

Gambar 4. Kegiatan pendampingan belajar daring, berbasis aplikasi media whatshApp

\section{Program Pelaksanaan Pembelajaran dalam Rangka Meningkatkan Kemampuan Motorik Kasar Melalui Pembelajaran Online (Daring) Berbasis Aplikasi Whats App}

Kegiatan ini dalam pelaksanaan program pembelajaran online (daring) berbasis aplikasi whatsapp grup dalam rangka untuk meningkatkan kemampuan motorik kasar anak yang dilakukan di rumah masing-masing, dalam kegiatan ini secara teknis,para guru dapat mempersiapkan pembelajaran 
yang meningkatkan kemampuan motorik kasar anak, melalui video pembelajaran yang dibuat guru untuk anak dapat mencoba ataupun dapat melakukan nya di rumah masing-masing.

Evaluasi pembelajaran online yaitu peserta didik dapat mengirimkan hasil kegiatan belajar anak di rumah melalui foto/vidio yang dilakukan anak saat mencoba melakukan sesai contoh atau arahan yang diberikan guru melalui vidio pembelajaran.

Adapun program yang terlaksana dari siklus 1-2 berdasarkan pada perencaanaan, pelaksanaan dan juga penilaian yang dilakukan adalah sebagai berikut:

Tabel 1: Program pengembangan aspek motoric kasar yang berhasil dilaksanakan

\begin{tabular}{|c|l|c|}
\hline No & \multicolumn{1}{|c|}{ Kegiatan Motorik Kasar } & Indikator Capaian \\
\hline 1 & Menyapu Halaman & Terlaksana \\
\hline 2 & Bermain Maze (Umbi-umbian) & Terlaksana \\
\hline 3 & Bermain Boling dengan Bawang Bombay & Terlaksana \\
\hline 4 & Menyusun Kata dengan Lari & Tidak Terlaksana \\
\hline 5 & Menangkap dan Melempar Kentang & Terlaksana \\
\hline 6 & Senam Corona & Terlaksana \\
\hline 7 & Gerak dan Lagu (Kentang) & Terlaksana \\
\hline \multicolumn{2}{|l}{ Keterangan: } \\
Isi dengan Terlaksana dan Tidak Terlaksana
\end{tabular}

\section{Rencana Tahapan Selanjutnya (Refleksi)}

Tindak lanjut dari kegiatan fisik motorik kasar kepada peserta didik: Guru membuat vidio pembelajaran terlebih dahulu sesuai RPPM daring lalu guru membagikan vidio pembelajran melalui grup whatsapp kelas B. Peserta didik melihat vidio pembelajaran yang buat guru, dan anak melakukan kegiatan sesuai arahan dan contoh yang di kirimkan guru. Untuk melalukan evaluasi pembelajaran anak dalam proses penilaian dapat dilakukan secara sistematis serta objektif sesuai dengan RPPM daring yang telah di rancang sesuai tujuan untuk meningkatkan kemampuan motorik kasar anak yang di buat guru. Tujuannya untuk mengetahui perkembangan motorik kasar peserta didik RA Al Muttaqin melalui vidio yang dikirimkan peserta didik melalui aplikasi Whats App grup untuk guru dapat melakukan penilaian.

Dalam hal yang perlu diperhatikan ialah agar seorang guru serta orang tua peserta didik dapat bekerjasama untuk mendidik, menjaga, serta memberikan motivasi anak dalam belajar serta meminimalisir stress belajar pada peserta didik. Hal itu bisa dilakukan melalui cara pemberian tugastugas yang mudah, menarik dan menyenangkan untuk anak belajar dirumah serta pengelolaan suasana lingkungan belajar yang baik. Hingga dari itu baik teknologi, seorang guru serta orang tua peserta didik sangat berperan penting dalam proses kegiatan belajar mengajar dalam pembelajaran daring di masa pandemi ini.

Kerjasama seorang pendidik dan guru akan dapt berjalan dengan lancer apabila terjalin komunikasi yang baik seperti dikemukakan oleh (Syahputra, 2020) dimana peran sangat besar kan 
dilakukan orang tua dalam pembelajaran pandemic. Ditegaskan juga oleh (Solekah et al., 2021) media yang digunakan dalam pemilihan kegiatan terutama Whats App efektif mudah diakses orang tua dengan mobile gawai HP android yang dimiliki dan memudahkan berkomunikasi. Tinggal sekolah menyesuaikan dengan pedoman penyelenggaran pembelajaran yang ditetapkan dan mengikuti perkembangan kebijakan oleh pemerintah (Kemdikbud \& Kemdikbud, 2020). Selain itu sekolah harus terus mengupayakan media yang efektif dan menarik yang akan digunakan dalam motoric kasar seperti dikemukakan oleh (Sucipto Dwijo et al., 2020) apabila kurang maksimal harus digali selain Whats Appbisa digunakanmedia pembelajaran yang lain.(Lestariningrum, 2019) menguatkan betapa pengembangan motoric kasar anak apabila dilakukan dengan menyenangkan akan membuat anak termotivasi dan juga membantu pengembangan aspek lainnya.

\section{SIMPULAN}

Berdasarkan hasil kegiatan didapat simpulan yaitu bahwa kemampuan motorik kasar adalah salah satu kemampuan dasar yang harus distimulasi dan dikembangkan pada anak usia dini. Guru perlu meningkatkan kemampuan motorik kasar anak dengan menciptakan situasi belajar di rumah yang dapat memberikan rasa aman dan menyenangkan dengan konsep belajar bermain sambil belajar. 2) Setiap orang tua peserta didik, keterlibatannya orang tua dalam meningkatkan kemampuan motorik kasar anak sangat diperlukan. Berdasarkan kemampuan motorik kasar anak tidak bisa dipisahkan dari kehidupan manusia sejak anak lahir. Oleh sebab itu orang tua peserta didik hendaknya telah menstimulasi kemampuan motorik kasar anak dari sejak usia dini.

Pembelajaran online (daring) berbasis aplikasi whatsapp grup mampu meningkatkan kemampuan motorik kasar anak dalam proses pembelajaran yang di rancang sesuai kemampuan anak usia 5-6 tahun sehingga anak dapat lebih kreatif, inovatif serta menjadi kepribadian yang mandiri. Apabila materi yang disampaikan pada aplikasi wqhatsapp dirancang secara detail, dan sistematis, maka pembelajaran daring di RA Al Muttaqin kecamatan Pondokgede dapat meningkatkan pengetahuan anak dan mumbuhkan rasa percaya diri anak saat mencoba mengirimkan tugas melalui vidio yang akan dikirim ke guru.

\section{DAFTAR RUJUKAN.}

Fikriyati, Mirroh. 2013. Perkembangan Anak Usia Emas (Golden Age). Yogyakarta: Laras Media Prima.

Kusumaningtyas, Lydia Ersta. 2016. Bermain dalam rangka Mengembangkan Motorik pada Anak Usia Dini. Universitas Slamet Riyadi Surakarta, Indonesia. http://journal.umpo.ac.id/index.php/indria/article/view/227

Kemdikbud, \& Kemdikbud, pengelola web. (2020). Pedoman Penyelenggaraan Belajar dari Rumah. In Jakarta, 28 Mei 2020 (pp. 8-9).

https://www.kemdikbud.go.id/main/blog/2020/05/kemendikbud-terbitkan-pedomanpenyelenggaraan-belajar-dari-rumah

Lestariningrum, A. (2019). Pengaruh Senam Bebek Berenang Terhadap Kemampuan Motorik Kasar Anak Usia 3-4 Tahun. Efektor, 6(1), 1-6. http://ojs.unpkediri.ac.id/index.php/efektore/article/view/12606

Solekah, M., Lestariningrum, A., Dwiyanti, L., \& Un, P. (2021). Implementasi Pembelajaran Nilai Agama Dan Moral Pada Anak Usia 4-5 Tahun Selama Belajar Dari Rumah. 1(1), 67-79. 
Sucipto Dwijo, A.-Q. N. E., Indarwati, S., Suwandini, C. A. S., \& Mustainah, S. (2020). Penerapan Metode Pembelajaran Melalui Media WhatsApp Selama Pandemi COVID-19 di RA AI-Qodir. JECED : Journal of Early Childhood Education and Development, 2(2), 124-131. https://doi.org/10.15642/jeced.v2i2.840

Syahputra, M. C. (2020). Pendidikan Orang Tua Terhadap Anak dalam Menyikapi Pandemi COVID-19. Equalita: Jurnal Studi Gender Dan Anak, 2(1), 58. https://doi.org/10.24235/equalita.v2i1.7056

Malyana, Andasia. 2020.(Dinas Pendidikan dan Kebudayaan Kota Bandar Lampung)http://jurnal.stkippgribl.ac.id/index.php/pedagogia

Muhammad, Hamid. (2020). Kemendikbud Sebut PJJ Tak Sama dengan Pembelajaran Daring dan Luring", Artikel PENDIDIKAN. Jawapos.com, 17 Juni 2020, https://www.jawapos.com/nasional/pendidikan/17/06/2020/..., diunduh pada Juli 2020.

Sadjati, 2012. Hakikat Bahan Ajar. Universitas Terbuka. repository.ut.ac.id/4157/1//DIK4009-M1.pdf bahan ajarpdf

Subiyakto, B., Susanto, H., \& Akmal, H. (2019). Media Pembelajaran Sejarah Era Teknologi Informasi. Banjarmasin: Program Studi Pendidikan Sejarah, ULM.

Sudjana, Nana. 2005. Penilaian Hasil Proses Belajar Mengajar. Bandung. PT. Remaja Rosdakarya.

Sunendar, Dadang, dkk. (Tim Penyusun KBBI Edisi Kelima). (2020). Kamus Besar Bahasa Indonesia. Jakarta: Badan Pengembangan dan Pembinaan Bahasa, Kementerian Pendidikan dan Kebudayaan Republik Indonesia.

Syaharuddin, S. (2020). Pembelajaran Masa Pandemi: Dari Konvensional Ke Daring.

SE Mendikbud: Pelaksanaan Kebijakan Pendidikan dalam Masa Darurat Penyebaran Covid-19 24 Maret 2020.

Yuliani Nurani Sujiono (2009). Konsep Dasar Pendidikan Dasar Anak Usia Dini. Jakarta: PT Indeks. 